[Agr. Biol. Chem., Vol. 35, No. 4, p. 632 635, 1971]

\title{
Isolation of Possible Intermediate of Chlorogenic Acid Biosynthesis in Sweet Potato Root Tissue
}

Sir:

Chlorogenic acid is one of the most ubiquitous polyphenols in the plant kingdom, ${ }^{1,21}$ it plays important roles in some physiological functions of plants. For example, its involvement in the defense action in plants has been shown in our laboratory..$^{3 \sim 51}$ Radioisotopic experiments $^{6 \sim 91}$ revealed that $t$-cinnamic acid is the source of the aromatic moiety of chlorogenic acid. The pathway from $t$-cinnamic acid to chlorogenic acid which involves hydroxylation of the benzen ring and esterification, however, remains obscure, although several theories conflicting with each other have been proposed on the biosynthetic pathway. According to Levey and Zucker " and Runeckles, ${ }^{\text {") }}$ the first ester intermediates of chlorogenic acid biosynthesis are 3-O-cinnamoylquinic acid and 3-O-p-coumaroylquinic acid, respectively. On the other hand, El-Basyouni et al $^{101}$ suggested that the intermediates of phenylpropanoids in lignin biosynthesis are possible protein binding

1) A. F. Bradfield, A. E. Flood, A. C. Hulme and A. H. Williams, Nature, 170, 168 (1952).

2) D. Dickinson and J.H. Gawler, J. Sci. Fd. Agric., 5, 525 (1954).

3) I. Uritani and K. Muramatsu, Nippon Nogeikagaku Kaishi, 27, 29 (1953).

4) I. Uritani, ibid., 27, 165 (1953).

5) I. Uritani and M. Miyano, Nature, 175, 812 (1955).

6) D. R. McCalla and A.C. Neish, Can. J. Biochem. Physiol., 37, 537 (1959).

7) C. C. Levy and M. Zucker, J. Biol. Chem., 235, 2418 (1960).

8) K. R. Hanson, Phytochemistry, 5, 491 (1966).

9) V. C. Runeckles, Can. J. Biochem. Physiol., 41, 2249 (1963).

10) S.Z. El-Basyouni and A.C. Neish, Phytochemistry, 5, $683(1965)$. esters of cinnamic acid derivatives. In the preceding paper, ${ }^{11 /}$ we suggested the operation of the two pathways in sweet potato root tissue $:$ phenylalanine $\longrightarrow t$-cinnamic acid $\longrightarrow$ $t$-cinnamoyl derivative $\longrightarrow p$-coumaroyl derivative $\longrightarrow$ chlorogenic acid, and phenylalanine $\longrightarrow t$-cinnamic acid $\longrightarrow p$-coumaric acid $\longrightarrow$ $p$-coumaroyl derivative $\longrightarrow$ chlorogenic acid.

As reported previously, ${ }^{3 \sim 51}$ polyphenolic compounds, mainly composed of chlorogenic acid and isochlorogenic acid, are markedly synthesized in sweet potato root tissue in response to slicing. It has also been demonstrated that some enzymes involved in the biosynthesis of the compounds are formed prior to their prominent synthesis. ${ }^{12-15}$ This communication deals with the finding of a possible intermediate in chlorogenic acid biosynthesis in sweet potato root tissue and some of its properties.

$t$-Cinnamic acid-2 $-{ }^{14} \mathrm{C}$ was prepared in a pure form by the Perkin reaction modified by Doebner. ${ }^{161}$ One $\mathrm{ml}$ of $5 \mathrm{mM}$ acetate buffer, pH 5.5, containing $12.5 \mu$ moles of $t$ cinnamic acid-2- ${ }^{14} \mathrm{C}, 70.5 \mathrm{~m} \mu \mathrm{Ci}$ per $\mu$ mole,

11) M. Kojima, T. Minamikawa, H. Hyodo and I. Uritani, Plant and Cell Physiol., 10, 471 (1969).

12) T. Minamikawa and I. Uritani, Arch. Biochem. Biophys., 108, 573 (1964).

13) T. Minamikawa, M. Kojima and 1. Uritani, ibid., 117, 194 (1966).

14) T. Minamikawa, M. Kojima and I. Uritani, Plant and Cell Physiol., 7, 583 (1966).

15) M. Kojima, T. Minamikawa and I. Uritani, ibid., 10, 245 (1969).

16) O. Doebner, "Organic Reaction,' Vol. I. ed. by R. Adams et al. John Wiley and Sons. Inc., New York, N.Y., 1957, p. $248 \sim 249$. 


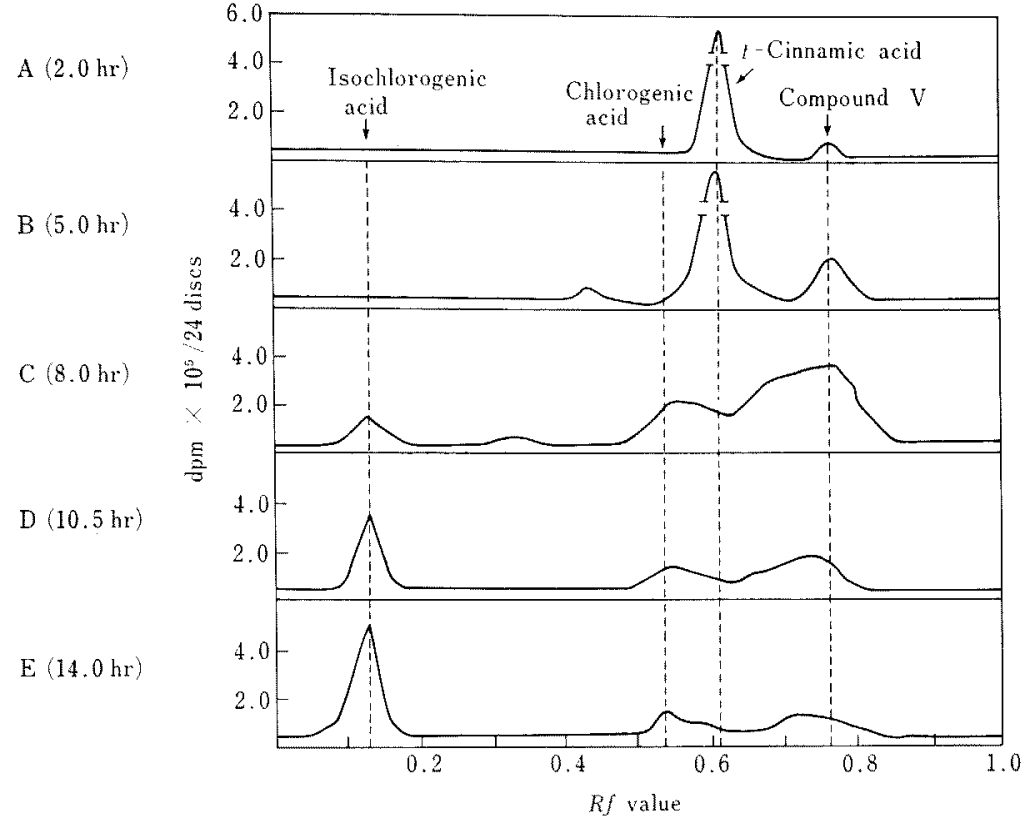

FIG. 1. Paper Radiochromatograms of Ethanol Extracts of Sweet Potato Root Discs Administrated with Cinnamic Acid-2-14C.

The ethanol extracts were subjected to paper chromatography (5\% acetic acid). After development, the paper strips were cut into $1 \mathrm{~cm}$ pieces, which were assayed for radioactivity in a liquid scintillation spectrometer. Arrows on chromatograms represent the migrating positions of the individual compounds in the solvent system (5\% acetic acid). A, B, C, D and E: radiochromatograms after $2.0 \mathrm{hr}-, 5.0 \mathrm{hr}-, 8.0 \mathrm{hr}-, 10.5 \mathrm{hr}$, and $14.0 \mathrm{hr}$-incubation, respectively.

was administrated to 24 discs $(2 \times 19 \mathrm{~mm})$ of tissue, which were incubated at $30^{\circ} \mathrm{C}$ for appropriate periods. After incubation, the discs were washed with $100 \mathrm{ml}$ of water, boiled in $30 \mathrm{ml}$ of ethanol and homogenized. The homogenate was boiled in a hot water bath for $30 \mathrm{~min}$, and filtered. The resultant ethanol extract was subjected to silica gel column chromatography developed by Hanson and Zucker $^{17 \gamma}$ and paper chromatography $(5 \% \%$ acetic acid) to investigate the time-course changes in distribution of radioactivity during incubation. As shown in Fig. 1, radioactivity of $t$-cinnamic acid- $2-{ }^{14} \mathrm{C}$ was distributed in compound $\mathrm{V}$ (tentatively called) first, in $2 \mathrm{hr}$

17) K. R. Hanson and M. Zucker, J. Biol. Chem., 238, 1105 (1963). after administration, then appeared in chlorogenic acid, and finally in isochlorogenic acid. Thin-layer chromatography as well as paper chromatography indicated that compound $\mathrm{V}$ consisted of a single component. The results strongly suggest that the compound is an intermediate of chlorogenic acid biosynthesis. Furthermore, time-course analysis with the column chromatography indicated that specific radioactivity of compound $\mathrm{V}$ increased prior to that of the fraction containing chlorogenic acid and isochlorogenic acid and decreased prior to that of the latter. This implies the precursor-product relationship. When the radioactive compound $\mathrm{V}$ isolated from the discs after administration of $t$-cinnamic acid$2-{ }^{14} \mathrm{C}$ was fed to other discs, the radioactivity was efficiently incorporated into chlorogenic 
acid and isochlorogenic acid, as shown in Table I. This supports the above view.

Compound $\mathrm{V}$ is an acidic substance show-

TABLE I. Distribution OF Radioactivity of VARIoUs Fractions IN SWEET POTATO RoOT Discs AFTER ADMINISTRATION OF LABELED COMPOUND $\mathrm{V}$

Twenty eight discs $(2 \times 19 \mathrm{~mm})$ were administrated with radioactive compound $\mathrm{V}\left(3.57 \times 10^{5} \mathrm{dpm}, 430\right.$ as O. $D_{278}$ in $1 \mathrm{ml}$ ) in $1 \mathrm{ml}$ of $5 \mathrm{mM}$ acetate buffer, $\mathrm{pH}$ 5.5 and incubated at $30^{\circ} \mathrm{C}$ for $18 \mathrm{hr}$.

\begin{tabular}{lccc}
\hline & $\begin{array}{c}\text { Radioac- } \\
\text { tivity dpm }\end{array}$ & $\begin{array}{c}\text { Radioac- } \\
\text { tivity } \%\end{array}$ & $\begin{array}{c}\text { Relative } \\
\%\end{array}$ \\
\hline Administrated & $3.57 \times 10^{5}$ & 100 & \\
Unabsorbed & $0.96 \times 10^{4}$ & 3 & \\
Insoluble Fraction & $1.36 \times 10^{5}$ & 38 & \\
$\mathrm{CO}_{2}$ & $1.08 \times 10^{5}$ & 30 & \\
EtOH extract ${ }^{\circ}$ & $1.03 \times 10^{5}$ & 29 & 100 \\
Chlorogenic acid & $0.21 \times 10^{5}$ & 6 & 20 \\
Isochlorogenic acid & $0.57 \times 10^{5}$ & 16 & 55 \\
\hline
\end{tabular}

a) Ethanol extract was subjected to paper chromatography (50\% acetic acid) to obtain the fractions of chlorogenic acid and isochlorogenic acid.

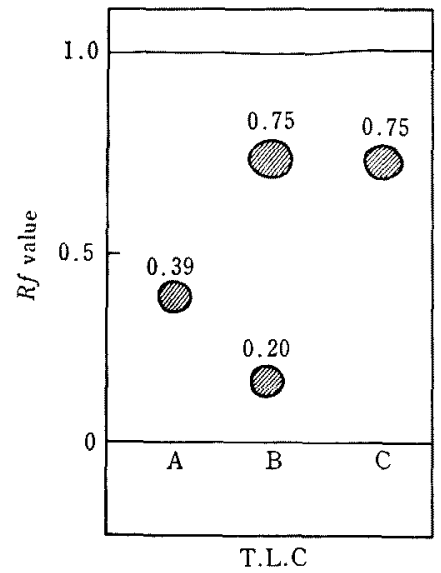

( I ) ing maximum absorption at $278 \mathrm{~m} \mu$ in either ethanol or water. The UV spectrum without alkaline shift suggested the absence of phenolic hydroxyl group(s) in its structure. Compound $\mathrm{V}$ is unstable in alkaline solution and hydrolized to two components easily (Fig. 2). Radioactivity of compound $\mathrm{V}$ was strictly confined to one of the two components (the spot of $R f 0.75$ or 0.58 on thin-layer or paper chromatogram in Fig. 2), which was proved to be $t$-cinnamic acid based on paper and thin-layer chromatographies, and UV, IR and Mass-spectrometries. On the other hand, another component of compound $\mathrm{V}$ is presumed to be a substance carrying a carboxyl group and alcoholic hydroxyl groups, which is neither quinic acid nor shikimic acid, based on the data on IR spectrum and positive acidic reaction. Taken altogether, compound $\mathrm{V}$ is thought to be an intermediate of chlorogenic acid biosynthesis and be an ester of $t$ cinnamic acid with a substance carrying a carboxyl group and alcoholic hydroxyl groups different from 3-O-cinnamoylquinic acid and

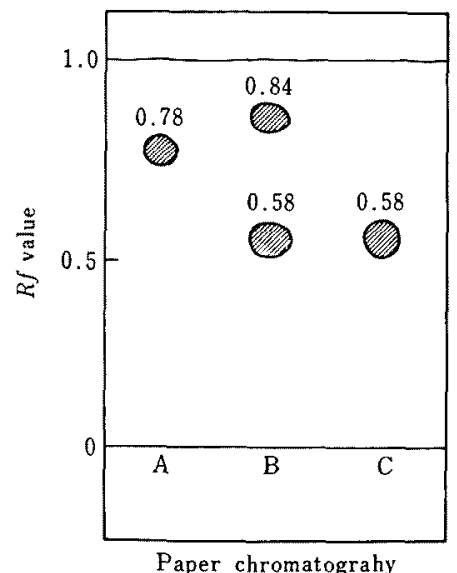

(II)

FIG. 2. Chromatograms of Compound $V$, Hydrolyzate of Compound V, and t-Cinnamic Acid.

Compound l: was kept in I $\mathrm{N}$ sodium hydroxide at room temperature for $12 \mathrm{hr}$, and acidified with $5 \mathrm{~N}$ hydrochloric acid. An aliquot of hydrolyzate of compound $\mathrm{V}$, compound $\checkmark$ or $t$-cinnamic acid was subjected to silica gel thin-layer chromatography (I. toluene-ethyl formate tormic acid. 5.4:1) and paper chromatography (II. 5\% acetic acid). A, B and C: compound $\mathrm{V}$, hydrolyzate of compound $\mathrm{V}$ and $\mathrm{t}$-cinnamic acid, respectively. 
3-0-p-coumaroylquinic acid.

IkUzo URITANI

The authors wish to express their thanks to Dr. M. Zucker of Connecticut Agricultural Experiment Station for kind gift of 3-O-cin-

Department of Agricultural Chemistry

Received February 3, 1971 namoylquinic acid.

Mineo Kojima 